\title{
ADMISSION CARDIAC TROPONINS PREDICT HOSPITAL MORTALITY IN TYPE A ACUTE AORTIC DISSECTION: A META-ANALYSIS OF ADJUSTED RISK ESTIMATES
}

\begin{abstract}
Mislav Vrsalović ${ }^{1,2}$ and Ana Vrsalović Presečki ${ }^{3}$
${ }^{1}$ University of Zagreb, School of Medicine, Zagreb, Croatia;

${ }^{2}$ Department of Cardiology, Sestre milosrdnice University Hospital Centre, Zagreb, Croatia;

${ }^{3}$ Faculty of Chemical Engineering and Technology, University of Zagreb, Zagreb, Croatia

SUMMARY - Acute aortic dissection (AAD) is a serious medical emergency that requires early diagnosis and rapid treatment. Whether cardiac troponin could be an independent prognostic marker in patients with type A AAD is still unknown. We systematically searched Medline and Scopus to identify all observational cohort studies published before January 2020 that compared outcome (inhospital mortality) in patients with type A AAD with and without troponin elevation on admission. Four studies with 412 patients were included in final analysis (median age 59 years, $65 \%$ of males). A total of $124(30 \%)$ patients died during in-hospital stay, and 73\% underwent surgery. Elevated troponins (39.6\% of patients) were associated with an increased risk of short-term mortality (adjusted odds ratio 1.26 ; $95 \%$ confidence interval $1.08-1.47)$, with low heterogeneity among studies $\left(I^{2}=29.81 \%\right)$. Elevated troponins on admission are independently associated with increased in-hospital mortality in type A AAD.
\end{abstract}

Key words: Troponin; Aortic dissection; Mortality; Meta-analysis

\section{Introduction}

Acute aortic dissection (AAD) is a serious medical emergency that requires early diagnosis and rapid treatment ${ }^{1}$. There is still lack of data on the role of circulating biomarkers in risk stratification of patients with AAD. Cardiac troponins, the preferred biomarker in diagnosing acute coronary syndromes, provide prognostic information in a broad spectrum of noncardiac conditions ${ }^{2}$. Troponin elevation among patients with $\mathrm{AAD}$ is common, and may be associated

Correspondence to: Mislav Vrsalovic, MD, PhD, FESC, FSVM, Department of Cardiology, Sestre milosrdnice University Hospital Centre, Vinogradska c. 29, HR-10000 Zagreb, Croatia

E-mail: mislav.vrsalovic@gmail.com

Received December 16, 2020, accepted February 2, 2021 with in-hospital diagnostic delay and misdiagnosis ${ }^{3,4}$. This becomes even more important after the introduction of high-sensitivity troponins in routine clinical practice $^{2}$. We conducted a systematic review with meta-analysis to evaluate whether admission troponin positivity was associated with an increased risk of hospital mortality in patients with type A AAD.

\section{Material and Methods}

This meta-analysis was performed in accordance with the PRISMA statement ${ }^{5}$. We systematically searched Medline and Scopus to identify all observational cohort studies published before January 2020 that compared outcome (in-hospital mortality) in patients with type A AAD (presented within 14 days of 


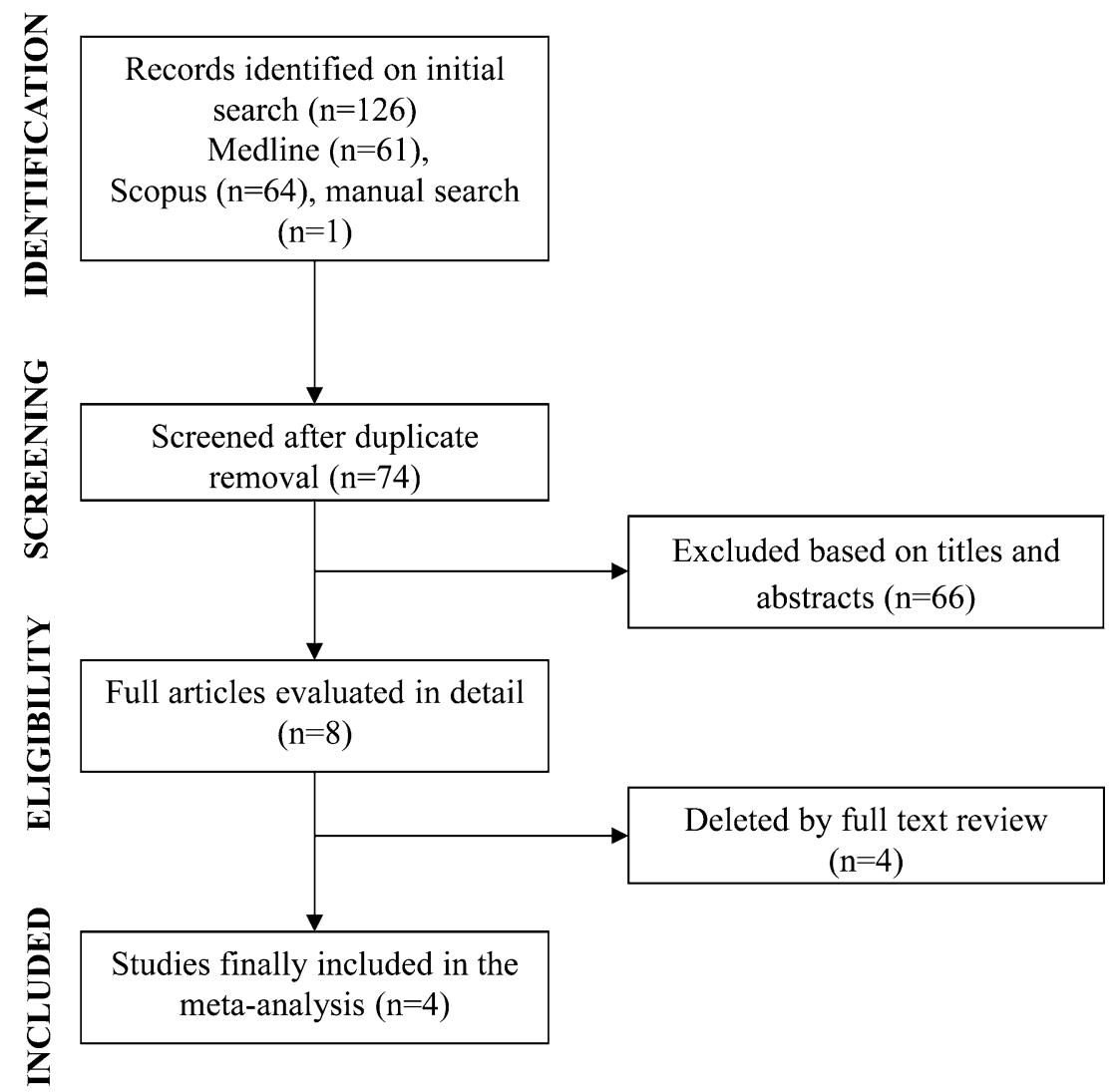

Fig. 1. Study flow diagram for meta-analysis of cardiac troponins and type $A$ acute aortic dissection in-hospital mortality.

symptom onset) with and without troponin elevation on admission, combining terms "troponin" and "aortic dissection". Study selection and data extraction were conducted independently by two investigators (MV and AVP), and study quality was evaluated using the validated Newcastle-Ottawa Scale ${ }^{6}$. Completed database contained the following data: the name of the first author, year of publication, country of origin, total number of patients in each study, study design, mean age of a population, the percentage of males and $\mathrm{pa}^{-}$ tients with hypertension, type of troponin and diagnostic assay, cut-off value, in-hospital mortality, adjusted effect estimates, and confounding factors.

A meta-analysis was conducted using the generic inverse variance method, and pooled odds ratio (OR) was reported with $95 \%$ confidence interval (CI). Heterogeneity among studies was investigated using the Cochrane's Q test and $I^{2}$ statistic. Statistically significant heterogeneity was considered to be present at $\mathrm{p}<0.10$ and $I^{2}>50 \%$. Publication bias was assessed graphically using a funnel plot. Analyses were conducted using MedCalc Version 19.1.5 statistical software.

\section{Results}

A total of 126 citations were obtained by electronic search. After reading titles and abstracts, followed by review of the potentially relevant studies, four studies were included in final analysis, including a total of 412 patients (Fig. 1, Table 1) ${ }^{7-10}$. Median age of the population was 59 (range 54 to 69 ) years, $65 \%$ were males (range $57 \%$ to $70 \%$ ), and $70 \%$ had hypertension (range $50 \%$ to $93 \%$ ). Two studies were retrospective ${ }^{7,8}$ and two were prospective by design ${ }^{9,10}$. Multivariate statistical analysis was performed in all these studies. Using the Newcastle-Ottawa scoring system, scores ranged from 8 to 9 for the included studies.

Overall, 124 (30\%) patients with type A AAD died during hospital stay, and 73\% underwent surgery. E1evated cardiac troponin was present in $39.6 \%$ of pa- 


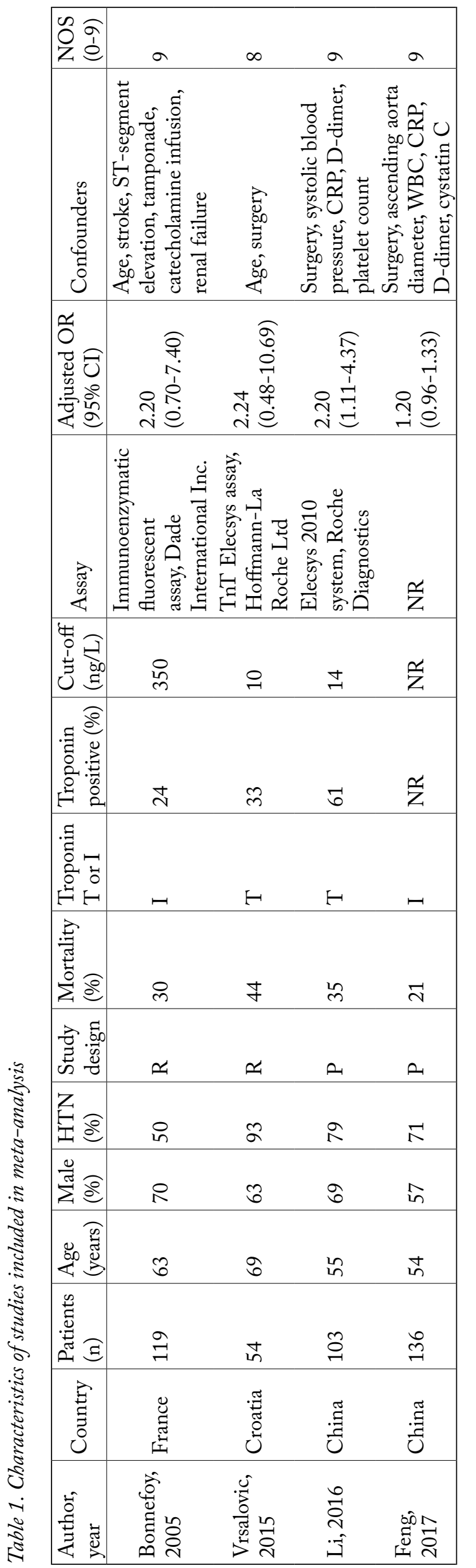

Troponins in type A acute aortic dissection: a meta-analysis

A)

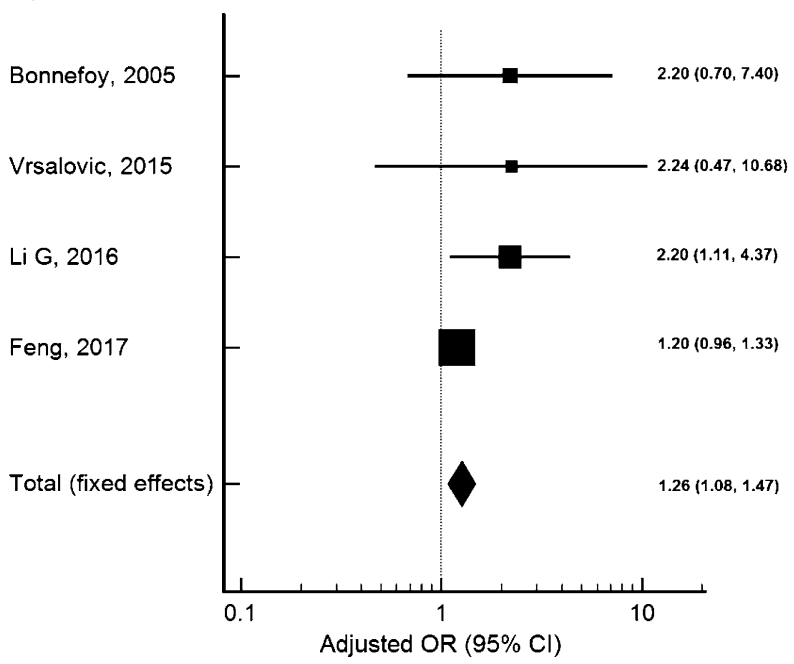

B)

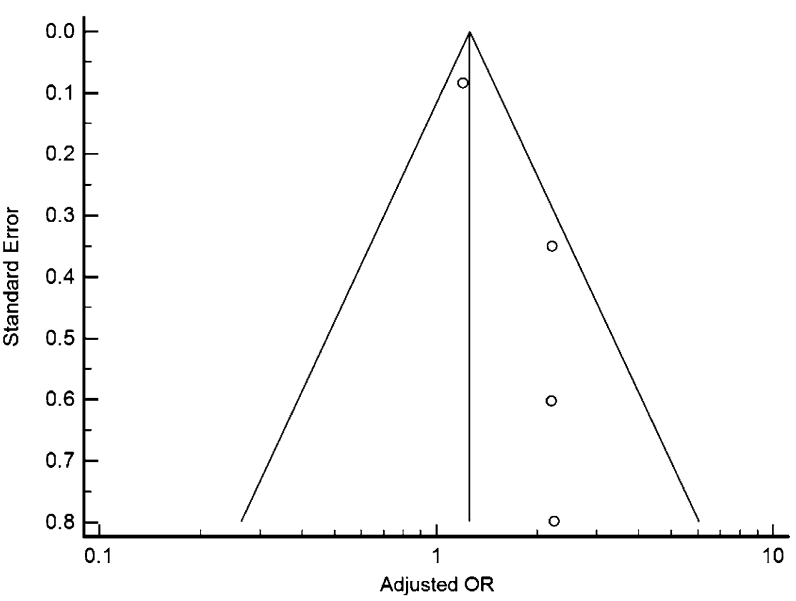

Fig. 2. Meta-analysis of studies testing the association between cardiac troponin elevation on admission and in-hospital mortality in type $A A A D(N=412):(A)$ meta-analysis of studies that reported adjusted ORs (generic inverse variance method, fixed effects model); (B) funnel plot of adjusted ORs of in-hospital mortality.

$\mathrm{AAD}=$ acute aortic dissection; $\mathrm{CI}=$ confidence interval; $\mathrm{OR}=$ odds ratio

tients, ranging between $24 \%$ and $61 \%$. Meta-analysis of studies that reported adjusted ORs (fixed effects model $)^{7-10}$ showed a significant association between elevated troponin values and mortality (OR, 1.26; 95\% CI, 1.08-1.47) (Fig. 2A). Analysis of pooled studies showed low heterogeneity $\left(I^{2}=29.81 \%, \mathrm{Co}^{-}\right.$ chrane $\mathrm{Q}=4.27, \mathrm{p}=0.23$ ) and funnel plot asymmetry (Fig. 2B). 


\section{Discussion}

Our meta-analysis showed for the first time that elevated cardiac troponins are independently associated with increased in-hospital mortality in mostly hypertensive patients with type A AAD.

Aortic dissection is a life-threatening condition with various clinical presentations, which requires immediate diagnostic assessment and therapy ${ }^{1}$. Troponin positivity is a common finding in patients with AAD, who can easily be misdiagnosed by physicians for other causes of acute chest pain (i.e. myocardial infarction, pulmonary embolism $)^{2-4}$. The prognostic role of troponins is already established in cardiovascular conditions such as acute coronary syndrome, pulmonary embolism, and acute ischemic stroke ${ }^{2}$. To date, a few biomarkers demonstrated the potential for risk stratification of patients with $\mathrm{AAD}^{3,11,12}$. According to our previous meta-analysis that included patients with both type $\mathrm{A}$ and type $\mathrm{B} \mathrm{AAD}$, troponin elevation was associated with an increased risk of in-hospital mortali$t^{3}$. The present study extended the previous findings, analyzing the adjusted effect estimates for outcome and focused exclusively on type A AAD that is treated differently with worse in-hospital outcomes compared to type B AAD. This is of importance in clinical assessment and differential diagnosis, since the risk of death for type A AAD increases by 3-4 percent every hour until the patient undergoes surgery ${ }^{1}$. The predictive value of troponin for myocardial damage is the result of several factors, including supply-demand imbalance due to severe drop in blood pressure, demand ischemia from severe aortic regurgitation, an intimal flap covering the coronary ostia, pressure overload from resistant hypertension and left ventricular dysfunction, or associated coronary artery disease ${ }^{3,4}$.

Along with the data reported in the International Registry of Acute Aortic Dissection, in our meta-analysis aortic dissection was reported predominantly in hypertensive men in the sixth decade of life $^{1}$. Troponin positivity on admission was common and provided clear and independent prognostic information in type A AAD. Clinicians should bear it in mind in the evaluation, differential diagnosis, management and followup of patients with a history of hypertension and acute chest pain. More research is needed to evaluate the role of troponins in the whole spectrum of patients with acute aortic syndromes.
In conclusion, our meta-analysis clearly showed the independent prognostic value of admission troponin elevation for in-hospital mortality in patients with type A AAD.

\section{References}

1. Evangelista A, Isselbacher EM, Bossone E, et al.; IRAD Investigators. Insights from the International Registry of Acute Aortic Dissection: a 20-year experience of collaborative clinical research. Circulation. 2018;137(17):1846-60. doi: 10.1161/ CIRCULATIONAHA.117.031264.

2. Lippi G, Cervellin G, Sanchis-Gomar F. Predicting mortality with cardiac troponins: recent insights from meta-analyses [published online ahead of print, 2019 Oct 17]. Diagnosis (Berl). 2019;/j/dx.ahead-of-print/dx-2019-0061/dx-20190061.xml. doi:10.1515/dx-2019-0061

3. Vrsalovic M. Prognostic effect of cardiac troponin elevation in acute aortic dissection: a meta-analysis. Int J Cardiol. 2016; 214:277-8. doi: 10.1016/j.ijcard.2016.03.230.

4. Vagnarelli F, Corsini A, Bugani G, et al. Troponin T elevation in acute aortic syndromes: frequency and impact on diagnostic delay and misdiagnosis. Eur Heart J Acute Cardiovasc Care. 2016;5(7):61-71. doi: 10.1177/2048872615590146

5. Moher D, Liberati A, Tetzlaff J, Altman DG. The PRISMA Group (2009). Preferred Reporting Items for Systematic Reviews and Meta-Analyses: The PRISMA Statement. PLoS Med 6(6):e1000097. doi:10.1371/journal.pmed1000097

6. Wells GA, Shea B, O'Connell D, et al. The Newcastle-Ottawa Scale (NOS) for assessing the quality of nonrandomized studies in meta-analyses. Ottawa, Canada: Ottawa Health Research Institute, 1999. Available from: www.ohri.ca/programs/clinical_epidemiology/oxford.asp. Accessed January 8, 2020.

7. Bonnefoy E, Godon P, Kirkorian G, Chabaud S, Touboul P. Significance of serum troponin I elevation in patients with acute aortic dissection of the ascending aorta. Acta Cardiol. 2005;60(2):165-70. doi: 10.2143/AC.60.2.2005027.

8. Vrsalovic M, Zeljkovic I, Presecki AV, Pintaric H, Kruslin B. $\mathrm{C}$-reactive protein, not cardiac troponin $\mathrm{T}$, improves risk prediction in hypertensives with type A aortic dissection. Blood Press.2015;24(4):212-6.doi: 10.3109/08037051.2015.1025607

9. Li G, Wu XW, Lu WH, et al. High sensitivity cardiac troponin $\mathrm{T}$ : a biomarker for the early risk stratification of type-A acute aortic dissection? Arch Cardiovasc Dis. 2016;109(3):163-70. doi: 10.1016/j.acvd.2015.09.007

10. Feng WZ, Zhou JQ, Yu GM, Zeng Y, Xu P. Association of serum cystatin $\mathrm{C}$ levels with mortality in patients with acute type A aortic dissection. Oncotarget. 2017;8(60):101103-11. doi: 10.18632/oncotarget.20593

11. Vrsalović M, Vrsalović Presečki A. Admission C-reactive protein and outcomes in acute aortic dissection: a systematic review. Croat MedJ.2019;60(4):309-315. doi:10.3325/cmj.2019.60.309

12. Vrsalovic M, Vrsalovic Presecki A, Aboyans V. N-terminal pro-brain natriuretic peptide and short-term mortality in acute aortic dissection: a meta-analysis. Clin Cardiol. 2020;43(11): 1255-9. doi: $10.1002 / \mathrm{clc} .23436$ 
Sažetak

\title{
SRČANI TROPONINI PRETKAZUJU BOLNIČKU SMRTNOST \\ U BOLESNIKA S AKUTNOM DISEKCIJOM AORTE TIPA A: META-ANALIZA PRILAGOĐENIH OMJERA IZGLEDA
}

\author{
M. Vrsalović i A. Vrsalović Presečki
}

Akutna disekcija aorte $(\mathrm{AD})$ predstavlja životno ugrožavajuće hitno stanje koje zahtijeva ranu dijagnozu i liječenje. Do sada nije istraživana uloga srčanog troponina kao nezavisnog prognostičkog biljega u bolesnika s AD tipa A. Sustavno su pretražene baze podataka Medline i Scopus s ciljem pronalaska opservacijskih kohortnih studija objavljenih do siječnja 2020. godine, koje su uspoređivale bolničku smrtnost bolesnika s tipom A AD u ovisnosti o povišenim vrijednostima troponina u trenutku prijma. U istraživanje su uključene četiri studije s ukupno 412 bolesnika (medijan dobi 59 godina, $65 \%$ muškaraca). Ukupno su tijekom hospitalizacije umrla 124 (30\%) bolesnika, od kojih je 73\% podvrgnuto kirurškom liječenju. Povišene vrijednosti srčanih troponina $(39,6 \%$ bolesnika) bile su nezavisno povezane s povišenim rizikom kratkoročne smrtnosti (prilagođeni omjer izgleda 1,26; $95 \%$ interval pouzdanosti 1,08-1,47), uz nisku heterogenost među uključenim istraživanjima $\left(I^{2}=29,81 \%\right)$. Povišene vrijednosti troponina u trenutku prijma nezavisno su povezane s povišenom bolničkom smrtnošću u bolesnika s AD tipa A.

Ključne riječi: Troponin; Disekcija aorte; Smrtnost; Meta-analiza 